\title{
Spring defoliation effects on bluebunch wheatgrass: II. Basal area
}

\author{
PATRICK E. CLARK, WILLIAM C. KRUEGER, LARRY D. BRYANT, AND DAVID R. THOMAS
}

\begin{abstract}
Authors are range scientist, USDA Agricultural Research Service, Boise, Ida. 83712; professor, Department of Rangeland Resources, Oregan State University, Corvallis, Ore. 97331; range ecologist, USDA Forest Service, Washington, D.C. 20250; and professor, Department of Statistics, Oregon State University, Corvallis, Ore. 97331. At the time of the research, Clark was graduate research assistant, Department of Rangeland Resources, Oregon State University, Corvallis, Ore. 97331 and Bryant was wildlife biologist, USDA Forest Service, Pacific Northwest Research Station, La Grande, Ore. 97850.
\end{abstract}

\begin{abstract}
Spring livestock grazing has been suggested as a tool to improve winter forage quality of bluebunch wheatgrass (Agropyron spicatum [Pursh] Scribn. \& Smith). Impacts on plant vigor and survival are important concerns associated with spring grazing. We report basal area change and mortality responses of bluebunch wheatgrass to 3 spring, 1 winter, and 3 spring + winter defoliation treatments. The study was conducted in 1993 and 1994 at 2 sites in the Blue Mountains of northeastern Oregon. Basal area of individual plants was measured shortly after application of the spring treatments and again approximately 1 year after treatment. Clipping the entire basal area of bluebunch wheatgrass plants to a $7.6-\mathrm{cm}$ stubble height during the mid-boot phenological stage and during the inflorescence emergence stage produced 7.0 and $7.8 \%$ declines in live basal area, respectively. Unclipped control plants and plants having only one-half their basal area clipped to a 7.6-cm stubble height during the mid-boot stage exhibited 5.2 and $18.6 \%$ increases in live basal area, respectively. Combining the mid-boot/half-plant treatment with an early winter clipping to a $2.5-\mathrm{cm}$ stubble height reduced the positive live basal area response to $6.0 \%$. No additional declines in live hacal area relative to the spring-only treatments were detected for combinations of the early winter treatment with the midboot/whole plant treatment and the inflorescence emergence treatment. Experiment-wide plant mortality was only $0.2 \%$. If managed for a moderate level of defoliation where a portion of the basal area of each bunchgrass plant is left undefoliated, livestock grazing during the boot stage should have little negative impact on the vigor and survival of bluebunch wheatgrass under environmental conditions similar to northeastern Oregon.
\end{abstract}

Key Words: Agropyron spicatum, Cervus elaphus, elk, forage conditioning, mortality, phenology, plant vigor, winter range

Many authors have suggested livestock could be used as an effective tool for improving elk (Cervus elaphus) and mule deer (Odocoileus hemionus) habitat (Anderson and Scherzinger 1975, Malechek et al. 1978, Smith et al. 1979, Willms et al. 1980,

Research was funded by USDA Forest Service, Pacific Northwest Research Station, La Grande, Oregon and by Cooperative State Research Service. Authors wish to thank J. Cook, B. Dick, J. Kie, R. Riggs, E. Starkey, M. Vavra, and 3 anonymous reviewers for their critical review and comments on drafts of this manuscript.

Manuscript accepted 14 Mar. 1998.
Willms et al. 1981, Reiner and Urness 1982, Pitt 1986, Jourdonnais and Bedunah 1990, Urness 1990, Frisina and Morin 1991). Anderson and Scherzinger (1975) proposed late spring livestock grazing could be used to improve the forage quality on elk winter ranges dominated by perennial bunchgrasses such as bluebunch wheatgrass (Agropyron spicatum [Pursh] Scribn. \& Smith). Grazing bunchgrasses during the late spring requires special management attention since late spring represents a critical period in the phenology of cool-season bunchgrasses and improper grazing during this period could result in little or no regrowth and reduced plant vigor (Stoddart 1946, Blaisdell and Pechanec 1949, Wilson et al. 1966). Anderson and Scherzinger (1975) hypothesized if the intensity, duration and timing of defoliation were managed carefully, bunchgrass plants might be induced to produce regrowth of higher winter forage quality than undefoliated plants without critically reducing plant vigor.

Facilitative livestock grazing on rangeland dominated by bluebunch wheatgrass has apparently been successful in enhancing winter elk use (Anderson and Scherzinger 1975, Frisina and Morin 1991). Defoliation treatments applied during or after the boot stage have been shown to improve the winter forage quality of bluebunch wheatgrass (Pitt 1986, Clark et al. 1998). Under the environmental conditions of northeastern Oregon, however, an effective combination of phenological timing, duration, and intensity of defoliation for improving the winter forage quality of bluebunch wheatgrass without critically affecting plant vigor, survival, and regrowth production has not been experimentally identified. Summer regrowth in bluebunch wheatgrass, receiving a single defoliation to a 2.5 - or $7.6-\mathrm{cm}$ stubble height just prior to the boot stage, phenologically matured before aestivation and winter forage quality was not improved relative to undefoliated controls unless fall rains induced additional regrowth production (Bryant 1993). A single defoliation to a 7.6-cm stubble height, applied after plant maturity in early September, increased winter forage quality but sharply limited regrowth production of bluebunch wheatgrass on foothill rangeland in northeastern Oregon (Bryant 1993, Westenskow-Wall et al. 1994).

Our objective was to examine the effect of 3 spring, 1 winter, and 3 spring +winter defoliation treatments on basal area and mortality responses of bluebunch wheatgrass on elk winter range in northeastern Oregon. This experiment was conducted concurrently with an experiment examining forage quality responses of bluebunch wheatgrass to the 3 spring defoliation treatments (Clark et al. 1998). 


\section{Materials and Methods}

\section{Study Area}

The study was conducted during 1993 and 1994 within USDAForest Service big game winter range management arcas located near Starkey Experimental Forest and Range in the Blue Mountains of northeastern Oregon. Two study sites, McCarty Spring and Winter Ridge, selected for use in 2 previous studies (Bryant 1993, Westenskow-Wall et al. 1994), were utilized for the present study. Selection of these sites was based on 5 criteria: 1) location on an open ridge, 2) southerly to westerly aspect, 3) grassland vegetation type, 4) sufficient density of bluebunch wheatgrass plants for effective sampling, and 5) a consistent history of winter elk use. The McCarty Spring site was located at $1,274 \mathrm{~m}$ elevation with a gently sloping ( 0 to $5 \%)$ westerly aspect. The Winter Ridge site had a gently sloping ( 0 to $7 \%$ ) south-southwesterly aspect at 1,366 m elevation. See Clark et al (1998) for a detailed description of the vegetation and climatic conditions that prevailed at each site during the study.

Both the McCarty Spring and Winter Ridge sites had received moderate to heavy livestock grazing on an annual basis since 1864 (Skovlin 1991). A 0.5-ha livestock exclosure was constructed at each study site during the summer of 1986 . Two previous studies (Bryant 1993, Westenskow-Wall et al. 1994) and the present study were conducted within these exclosures.

\section{Experimental Design}

A split plot experimental design was used. At each study site, the area within the livestock exclosure (excluding a $10 \mathrm{~m}$ wide fence buffer zone) was divided into $10 \mathrm{~m}$ by $10 \mathrm{~m}$ whole plots. Thirty-two of the whole plots available at each study site were randomly assigned a late spring clipping treatment and year of application. Sixteen of the 32 whole plots at each site were used in 1993 and the remaining 16 whole plots were used in 1994. Sixteen bluebunch wheatgrass plants within each whole plot were selected randomly as subplots. The random selection of subplots was restricted to vigorous bluebunch wheatgrass plants with distinct basal area boundaries. Each subplot was tagged and photographed for later identification.

The 32 whole plots at each study site were randomly assigned to 1 of 4 treatments: 1) control, 2) mid-boot/whole-plant, 3) midboot/half-plant, and 4) inflorescence emergence/whole-plant. Bluebunch wheatgrass plants within the whole plots assigned the control treatment were left unclipped. Under the mid-boot/wholeplant and inflorescence emergence/whole-plant treatments, the cntire basal area of all the bluebunch wheatgrass plants within respective whole plots was hand-clipped to a $7.6-\mathrm{cm}$ stubble height during the mid-boot or inflorescence emergence phenological stage. One-half the basal area of all the individual bluebunch wheatgrass plants was clipped to a 7.6-cm stubble height during the mid-boot stage under the mid-boot/half-plant treatment. Choice of the 7.6-cm stubble height is described in Clark et al (1998). Each late spring clipping treatment was replicated in 4 whole plots at each study site.

Eight of the 16 subplots per whole plot were randomly assigned to a $2.5-\mathrm{cm}$ hand-clipping treatment applied during early November. This clipping treatment was designed to simulate the effects of early winter elk utilization on the vigor of plants defoliated during the previous spring. The remaining 8 subplots per whole plot were left unclipped as a subplot control. The entire experiment was replicated in 1994 on the remaining 16 whole plots at each study site.

Percentage mortality and percentage change in basal area of subplot bluebunch wheatgrass plants were evaluated during the hard seed phenological stage approximately 1 year following the application of the late spring clipping treatments (August 1994 and August 1995). The plants were visually inspected to determine percentage mortality. If there were no live tillers, the plant was considered dead. Percentage change in basal area of the subplot plants was used to assess plant vigor. An initial basal area measurement was taken for each subplot plant during the hard seed phenological stage approximately 2 months after the application of the late spring clipping treatments. Basal area was expressed as the product of the maximum length and the maximum width of the individual plants measured at ground level. The area of any dead spots within the basal area of each plant was similarly measured and this area value was subtracted from the total basal area to yield the live basal area of the plant. Percentage change in live basal area was assessed by comparing the initial basal area measurement to the final measurement taken one year later. Subplot plants classified as dead during the final basal area measurement were recorded as having a $100 \%$ negative change in basal area.

Percentage mortality and percentage change in live basal area were compared between subplot treatments, whole plot treatments, study sites, and years using general linear model procedures (SAS 1988). Where differences were detected, Fisher's Least Significant Difference (LSD) procedure was used to make multiple comparisons of treatment means based on the $5 \%$ level of significance (SAS 1988, Montgomery 1991).

\section{Results}

The experiment-wide mortality rate was only $0.2 \%$ of 1,024 plants treated. Highly significant whole plot treatment $(\mathrm{P}<0.01)$ and site $(P<0.01)$ effects on percentage change in live basal area were detected. The mid-boot/whole-plant treatment and the inflorescence emergence treatment produced declines in live basal area of bluebunch wheatgrass while the live basal area of plants receiving the unclipped control and the mid-boot/ half-plant treatments increased (Table 1). In 1993 at both the McCarty Spring and Winter Ridge sites, the percentage change in live basal area of plants receiving the mid-boot/half-plant treatment increased ( $P$ $<0.05$ ) compared to plants receiving the other 3 whole plot treatments (Fig. 1). Clipping treatments were generally more detrimental to plant vigor at the McCarty Spring site than at the Winter Ridge site $(\mathrm{P}<0.05)$. The McCarty Spring site was not as well-drained as the Winter Ridge site and plants at McCarty Spring seemed more prone to frost-heaving damage than plants at Winter Ridge. No significant year effects $(P=0.43)$ or site by year interactions $(P=0.33)$ were detected.

A subplot treatment effect was detected for percentage change in basal area $(P=0.05)$. Subplot plants receiving the midboot/half-plant whole plot treatment and the subplot control treatment had a significantly larger percentage increase in basal area $(P=0.05)$ than did subplot plants receiving both mid-boot/halfplant and early winter clipping (Table 1, Fig.1, 2). There was no statistical evidence of interactions between subplot treatments and whole plot treatments $(P=0.33)$. 


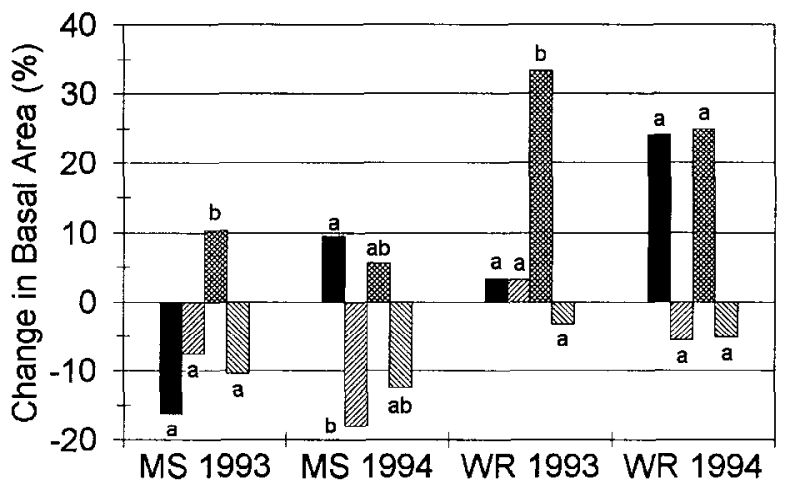

Unclipped Control Mid-Boot/Half-Plant

Mid-Boot/Whole-Plant Inflor. Emergence

Fig. 1. Percentage change in basal area of bluebunch wheatgrass plants receiving the whole plot treatments (late spring clipping) and receiving the control subplot treatment (no early winter clipping). Bars with different letter codes are significantly different within site/year combinations $(\mathrm{P}<0.05)$.

\section{Discussion}

\section{Competition}

The effect of competing plant species on forage quality and vigor of bluebunch wheatgrass was not directly evaluated in this study. Mueggler (1972) reported partial reduction of competition by neighboring plant species reduced the negative effect defoliation had on the vigor of bluebunch wheatgrass plants. In the present study, only bluebunch wheatgrass plants were clipped. Other plant species occurring in the experimental plots were not disturbed except for a slight amount of trampling damage occurring during application of the clipping treatments. Consequently, bluebunch wheatgrass plants receiving the clipping treatments may have been placed under greater competitive disadvantage than would occur in an actual grazing situation.

\section{Successive Defoliation}

Although the clipping treatments resulted in very limited mortality of subplot plants, this study did not examine the effect this level of defoliation would have on plant vigor and mortality if applied during several consecutive years. Bluebunch wheatgrass recovers vigor slowly (Mueggler 1975, Caldwell et al. 1981). Successive defoliations over several consecutive years may have a cumulative effect on plant vigor (Wilson et al. 1966, Rickard et al. 1975). Anderson and Scherzinger (1975) recommended forage conditioning treatments be applied under a rotation grazing system. However, forage conditioning under a rigid grazing system may not be as effective as a grazing management strategy which emphasizes maintenance of plant vigor and is flexible enough to respond to annual fluctuations in forage and environmental conditions.

\section{Grazing Systems}

Attempts to tailor grazing management systems to enhance forage quality on elk winter range should emphasize the sustainability of the plant resource. Findings from the present study support

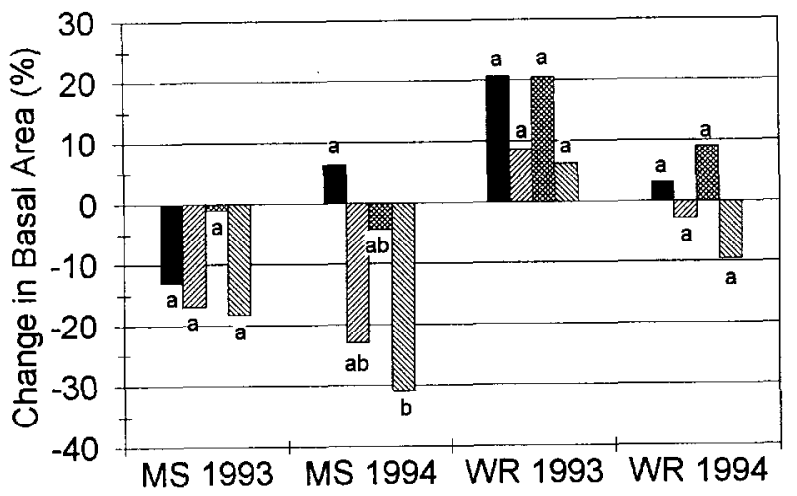

Unclipped Control Mid-Boot/Half-Plant

Mid-Boot/Whole-Plant inflor. Emergence
Fig. 2. Percentage change in basal area of bluebunch wheatgrass plants receiving the whole plot treatments (i.e. late spring clipping treatments) and the subplot clipping treatment (simulated early winter elk use). Bars with different letter codes are significantly different with site/year combination $P<0.05$ ).

the suggestions made by Anderson and Scherzinger (1975) that 1 potentially useful grazing management system for forage conditioning may be 1 designed to achieve a moderate level of defoliation of bluebunch wheatgrass plants during the boot stage. Defoliation of one-half the basal area of individual bluebunch wheatgrass plants to a $7.6-\mathrm{cm}$ stubble height during the mid-boot stage may enhance winter forage quality (Clark et al. 1998) and have no lasting negative effects on vigor relative to undefoliated plants (Table 1). Grazing systems utilizing the mid-boot/halfplant treatment for forage quality improvement, however, should include some provisions for vigor recovery to compensate for drought and other environmental stresses.

Complete defoliation to a 7.6- $\mathrm{cm}$ stubble height during the mid-boot or inflorescence emergence stage may result in a sizable improvement in forage quality relative to the mid-boot/half-plant and control treatments (Clark et al. 1998). Consequently, there may be considerable interest in applying these whole-plant treatments on big game winter range. Greater forage quality improvement under the mid-boot/whole-plant and inflorescence emergence treatments, however, may be offset by $8.5 \%$ and $13.1 \%$ declines in live basal area, respectively (Table 1). Hence, vigor recovery should he a primary focus in grazing systems employing these treatments.

To maintain healthy, vigorous plants under a forage conditioning regime, plants grazed in late spring must be allowed time to recover from the stress of defoliation. A grazing management strategy for late spring forage conditioning should be flexible and include several options for vigor recovery following defoliation. One option for vigor recovery after late spring defoliation may be early spring grazing during the following year. If defoliation is halted early enough in the growing season to allow complete phenological maturation of subsequent regrowth prior to aestivation, the effect on the vigor of bluebunch wheatgrass is minimum (Stoddart 1946, Blaisdell and Pechanec 1949, McLean and Wikeem 1985). A second option might be grazing deferment until late summer of the following year (i.e., after aestivation and 
Table 1. Comparison of whole plot and subplot treatment effects on percentage change in basal area of bluebunch wheatgrass. Means were calculated across years and study sites.

\begin{tabular}{|c|c|c|c|c|c|}
\hline \multicolumn{6}{|c|}{ Whole Plot Clipping Treatments } \\
\hline Subplot & & Mid-Boot & Mid-Boot & Inflor. & Std. Error \\
\hline Treatment & Control & Whole Plant & Half Plant & Emergence & Across Rows 1 \\
\hline & 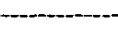 & $-\cdots(\%)$ & 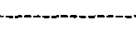 & & \\
\hline Without Simulated & $5.2^{\mathrm{abx}}$ & $-7.0^{\operatorname{ax}}$ & $18.6^{\mathrm{bx}}$ & $-7.8^{a x}$ & 7.6 \\
\hline Winter Elk Grazing & $(16.7)^{2}$ & $(8.7)$ & $(12.8)$ & (4.4) & (3 d.f.) \\
\hline With Simulated & $4.3^{\mathrm{ax}}$ & $-8.5^{a b x}$ & $6.0^{a y}$ & $-13.1^{b x}$ & 7.6 \\
\hline Winter Elk Grazing & $(13.8)$ & (14.3) & $(11.1)$ & $(15.5)$ & $(3$ d.f. $)$ \\
\hline Std Error & 4.9 & 4.9 & 4.9 & 4.9 & \\
\hline Within Columns ${ }^{3}$ & (1 d.f.) & (1 d.f.) & (1 d.f.) & (1 d.f.) & \\
\hline
\end{tabular}

${ }_{1}^{1}$ Standard error for whole plot treatment means and the degree of freedom used in the calculation.

2 Standard deviations are enclosed within parenthese below the means.

${ }^{3}$ Standard error for subplot treatment means and the degree of freedom used in the calculation

ab Means with different " $a$ " or " $b$ " letter codes within the first row represent significantly different whole plot treatment effects (P<0.0S).

$x y$ Means with different " $x$ " or " $y$ " letter codes within columns represent significantly different subplot treatment $e f f e c t s(P<0.05)$.

prior to the initiation of fall regrowth) or deferment until after heavy frosts begin to limit growth in the late fall of the following year. Deferring grazing until plant dormancy in late summer or late fall may minimize cumlative defoliation effects on vigor (Stoddart 1946, McLean and Wikeem 1985). Plants grazed in the late spring would have an entire growing season in the following year to recover losses of vigor. Cured leaves and culms might be removed by late season grazing, reducing the formation of "wolf plants" that would develop from the accumulation of standing litter. A third option could be a year-long rest from grazing. Anderson and Scherzinger (1975) recommended plants grazed in the late spring for 2 consecutive years should be rested from grazing for at least 1 year. Resting for 1 year, however, may reestablish some of "wolfy" characteristics in bluebunch wheatgrass, especially under moderate grazing. When bluebunch wheatgrass is under drought or other environmental stress, longer intervals of grazing deferment or rest may be needed between applications of late spring grazing.

\section{Management Implications}

Increasing elk populations in the western U.S. (Bryant and Maser 1982) and decreasing amounts of traditional elk winter range (Picton 1974, Peek et al. 1982, Vavra 1992, Sheehy and Vavra 1995) have prompted interest in using forage conditioning to increase winter elk use of public lands and decrease elk depredation on private lands. Moderate levels of spring defoliation can improve winter range forage quality and may prove extremely useful for manipulating elk distribution between private and public lands. Howevcr, careful control of elk population levels, rather than habitat enhancement, should be the primary focus in elk habitat management (Mohler and Toweill 1982). Forage conditioning is a tool to compliment rather than substitute good elk population management. Natural resource managers must continually reassess elk population levels and habitat availability. Target population levels for elk management should reflect changes in habitat availability, quality, and utilization. Finally, the public must become more well-informed regarding the need to limit elk populations. Prehaps then the biopolitical confusion of elk management might at least be reduced and decisions to reduce elk populations could then proceed more smoothly.

\section{Literature Cited}

Anderson, E.W. and R.J. Scherzinger. 1975. Improving quality of winter forage for elk by cattle grazing. J. Range Manage. 28:120-125.

Blaisdell, J.P. and J.F. Pechanec. 1949. Effects of herbage removal at various dates on vigor of bluebunch wheatgrass and arrowleaf balsamroot. Ecol. 30:298-305.

Bryant, L.D. 1993. Quality of bluebunch wheatgrass (Ayropyron spicatum) as a winter range forage for Rocky Mountain elk (Cervus elaphus nelsoni) in the Blue Mountains of Oregon. Ph.D. Diss., Oregon State Univ., Corvalis, Ore.

Bryant, L.D. and C. Maser. 1982. Classification and distribution, p. 1-59. In: J.W. Thomas and D.E. Toweill (eds.), Elk of North America: ecology and management. Stackpole Books, Harrisburg, Penn.

Caldwell, M.M., J.H. Richards, D.A. Johnson, R.S. Nowak, and R.S. Dzurec. 1981. Coping with herhivory: photosynthetic capacity and resource allocation in two semiarid Agropyron bunchgrasses. Oecologia 50:14-24.

Clark, P.E., W.C. Krueger, L.D. Bryant, and D.R. Thomas. 1998. Effect of late spring defoliation on bluebunch wheatgrass forage quality and quantity for wintering elk. J. Range Manage.

Frisina, M.R. and F.G. Morin. 1991. Grazing private and public land to improve the Fleecer Elk Winter Range. Rangelands 13:291-294.

Jourdonnais, C.S. and D.J. Bedunah. 1990. Prescribed fire and cattle grazing on an elk winter range in Montana. Wildl. Soc. Bull. 18:232-240.

Malechek, J.C., K.J. Kotter, and C.H. Jensen. 1978. Nutrition and production of domestic sheep managed as manipulators of big game habitat. J. Range Manage. 31:92-96.

McLean, A. and S. Wikeem. 1985. Influence of season and intensity of defoliation on bluebunch wheatgrass survival and vigor in southern British Columbia. J. Range Manage. 38:21-26.

Mohler, L.L. and D.E. Toweill. 1982. Regulated elk populations and hunter harvests, p. 561-597. In: J.W. Thomas and D.E. Toweill (eds.), Elk of North America: ecology and management. Stackpole Books, Harrisburg, Penn.

Montgomery, D.C. 1991. Design and analysis of experiments. 3rd ed. John Wiley \& Sons, New York, N.Y.

Mueggler, W.F. 1972. Influence of competition on the response of bluebunch wheatgrass to clipping. J. Range Manage. 25:88-92.

Mueggler, W.F. 1975. Rate and pattern of vigor recovery in Idaho fescue and bluebunch wheatgrass. J. Range Manage. 28:198-204.

Peek, J.M., R.J. Pedersen, and J.W. Thomas. 1982. The future of elk and elk hunting, p. 599-625. In: J.W. Thomas and D.E. Toweill (cds.), Elk of North America: ecology and management. Stackpole Books, Harrisburg, Penn. 
Picton, H.D. 1974. The Gallatin wildlife community. Gallatin Canyon Res. Monog. Montana State Univ., Bozeman, Mont.

Pitt, M.D. 1986. Assessment of spring defoliation to improve fall forage quality of bluebunch wheatgrass (Agropyron spicatum). J. Range Manage. 39:175-181.

Reiner, R.J. and P.J. Urness. 1982. Effect of horses managed as manipulators of big game winter range. J. Range Manage. 35:567-571.

Rickard, W.H., D.W. Uresk, and J.F. Cline. 1975. Impact of cattle grazing on three perennial grasses in south-central Washington. J. Range Manage. 28:108-112.

SAS. 1988. SAS/STAT user's guide. 6.03 ed. SAS Institute Inc. Cary, N.C.

Sheehy, D.P. and M. Vavra. 1995. Managing wildlife in incomplete habitats. In: L. Starr (ed.) Natural Resource News. 5:5-7. Blue Mountains Natural Resources Institute, La Grande, Ore.

Skovlin, J.M. 1991. Fifty years of research progress: A historical document on the Starkey Experimental Forest and Range. USDA For. Serv. Gen. Tech. Rep. PNW-GTR-266. Portland, Ore.

Smith, M.A., J.C. Malechek, and K.O. Fulgham. 1979. Forage selection by mule deer on winter range grazed by sheep in spring. J. Range Manage. 32:40-45.

Stoddart, L.A. 1946. Some physical and chemical responses of Agropyron spicatum to herbage removal at various seasons. Utah State Agr. College Agr. Exp. Sta. Bull. 324. Logan, Utah.
Urness, P.J. 1990. Livestock as manipulators of mule deer winter habitats in northern Utah, p. 25-38. In: K.E. Severson (ed.), Can livestock be used as a tool to enhance wildlife habitat. USDA For. Serv. Rocky Mt. For. and Range Exp. Sta. Gen. Tech. Rep. GTR-RM-194. Fort Collins, Colo.

Vavra, M. 1992. Livestock and big game forage relationships. Rangelands 14:57-59.

Westenskow-Wall, K.J., W.C. Krueger, L.D. Bryant, and D.R. Thomas. 1994. Nutrient quality of bluebunch wheatgrass regrowth on elk winter range in relation to defoliation. J. Range Manage. 47:240-244.

Willms, W., A.W. Bailey, and A. McLean. 1980. Effect of burning or clipping Agropyron spicatum in the autumn on the spring foraging behaviour of mule deer and cattle. J. Appl. Ecol. 17:69-84.

Willms, W. A.W. Bailey, A. McLean, and R. Tucker. 1981. The effects of fall defoliation of the utilization of bluebunch wheatgrass and its influence on the distribution of deer in spring. J. Range Manage. 34:16-18.

Wilson, A.M., G.A. Harris, and D.H. Gates. 1966. Cumulative effects of clipping on yield of bluebunch wheatgrass. J. Range Manage. 19:90-91. 